Науковий вісник Дьвівського націонадьного університету ветеринарної медицини та біотехнологій імені С.З. Гжицького

\author{
Scientific Messenger of Lviv National University \\ of Veterinary Medicine and Biotechnologies
}

\title{
The use of entropy analysis to evaluate the development of characteristics in dairy cattle of Holstein breed
}

\author{
T.V. Pidpala, A.S. Kramarenko, E.N. Zaitsev \\ Mykolayiv National Agrarian University, Mykolayiv, Ukraine
}

Received 4.01.2018

Received in revised form 8.02.2018

Accepted 15.02.2018

Mykolayiv National Agrarian University, G. Gongadze Str., 9 , Mykolayiv, 54020, Ukraine Tel.: +38-050-807-99-94

E-mail:pidpala@mnau.edu.ua
Article info

Pidpala, T.V., Kramarenko, A.S., \& Zaitsev, E.N. (2018). The use of entropy analysis to evaluate the development of characteristics in dairy cattle of Holstein breed. Scientific Messenger of Lviv National University of Veterinary Medicine and Biotechnologies. 20(84), 3-8. doi: 10.15421/nvlvet8401

The article presents the results of research on the evaluation of the development of dairy cattle characteristics in Holstein breed of different selection using entropy-information analysis (EIA). According to the studied indicators of dairy productivity their determinism is low, because there are many factors which influence the development of the signs. The degree of organization and informative content for Holstein breed cows of German and Ukrainian selection in adjacent generations has been established according to the basis characteristics of productivity, reproductive and adaptive ability of animals. The highest level of prevalence was characterized by signs of fat and protein content in milk as in the firstborn Holstein cows of German and Ukrainian breeding. Comparing to mothers, daughters have not only the highest level of informative content, but also have a bigger number of determinism. The probable influence of the "generation» factor was established only on the content of fat in milk. The smallest values of absolute organization the system were characterized by signs, the development of which is largely due to factors of environment. Signs which characterize reproductive and adaptive abilities of cows generally have lower entropy evaluations. This indicates their higher determinism and, consequently, biological importance. Especially it is true for the duration of the dry period in cows of the Holstein breed of German breeding. It is known that it causes physiological processes in the transitional period between two lactations and, accordingly to this, it influences the milk productivity of cows, especially, in the next lactation. Typically, according to the two signs (the duration of the first lactation and the duration of the given-birth period), we determined the probable effect of background (breeding) on the degree of their determinism (in both cases: $P<0.05)$. At the same time, according to these features in animals of German breeding the level of organization was higher than for Ukrainian selection of cows, regardless of generation. Thus, the use of EIA allows determining the effect of selection on the development of signs in dairy cattle. ability.

Key words: Holstein breed, entropy-information analysis, cows, milk productivity, a sign, reproductive

\section{Використання ентропійного аналізу для оцінки розвитку ознак молочної худоби голштинської породи}

\author{
Т.В. Підпала, О.С. Крамаренко, Є.М. Зайцев
}

Миколаївський національний аграрний університет, м. Миколаїв, Україна 
яких у значній мірі обумовлено факторами середовища. Ознаки, щчо характеризують відтворювальні та адаптаційні здатності корів, загалом мають нижчі очінки ентропї, шуо свідчить про їх вищу детермінованість і відповідно біологічну важливість. Особливо ие стосується тривалості сухостійного періоду в корів голитинської породи німецької селекиії. Як відомо, він обумовлює фізіологічні процеси у перехідний період між двома лактаціями й відповідно в значній мірі впливає на молочну продуктивність корів, особливо в наступну лактацію. Характерно, щчо відносно двох ознак (тривалість периої лактації та тривалість міжотельного періоду) нами було відмічено вірогідний вплив походження (селекиії) на ступінь їхньӧ̈ детермінованості (в обох випадках: P < 0,05). При цььому, у тварин німецької селекції рівень організованості за цими ознаками був вищим, ніж для корів української селекції, незалежно від генерації. Таким чином, використання ЕІА дозволяє визначити вплив селекції на розвиток ознак молочної худоби.

Ключові слова: голитинська порода, ентропійно-інформаційний аналіз, корови, молочна продуктивність, ознака, відтворювальна здатність.

\section{Вступ}

У процесі формування високопродуктивних конкурентоспроможних стад молочної худоби використовуються як вітчизняні племінні ресурси, так і генофонд порід зарубіжної селекції. Це своєю чергою зумовлює зміну генетичної структури популяції, що $\epsilon$ результатом комбінування генотипів і змін в технології виробництва продукції. Тому, важливим є визначення зміни балансу спадковості та розкриття процесів, що при цьому відбуваються (Zubec, 1997; Pidpala et al., 2012; Pidpala et al., 2016; Babik and Fedorovych, 2017; Golova et al., 2017; Kulibaba et al., 2017; Levitskaya, 2017; Ferenz, 2017; Pelekhaty et al., 2017).

Останнім часом почали використовувати інформаційно-статистичні методи, які надають змогу отримати більш детальні дані про рівень організації біологічних систем, гетерогенність популяцій, динаміку їхньої генетичної структури в процесі селекції. Ряд вчених (Merkur'eva and Bertazin, 1989; Palazzolo et al., 1998; Kramarenko, 2005; Patrieva and Kramarenko, 2007; Hyl, 2008; Grzesiak and Zaborski, 2012; Kramarenko et al., 2017; Gu et al., 2017) схиляються до думки, що перспективним тут $\epsilon$ ентропійноінформаційний аналіз (ЕIA).

Досліджуючи стан конкретної біологічної системи методом ентропійного аналізу, О.С. Милько (Mil'ko, 1993) одержав об'єктивні дані щодо впливу різних предків на розвиток породи і характер їх генетичної дії на нащадків, що дозволило довести значення глибокого генеалогічного аналізу в селекції.

На основі оцінки результатів ЕIA ознак молочної продуктивності корів голштинської породи встановлено рівень їх ентропії, а використання цих даних дозволило підвищити точність оцінки тварин і можливості різних варіантів відбору тварин для подальшого розведення (Smetana, 2009). Вважають, що фактичний ступінь вираженості значення $\mathrm{H}$ і О може бути доказом специфічно встановленої незмінної організованості полігенів (як результат комбінативної мінливості), а зміна прояву самих ознак у власному онтогенезі тварини - це є ефект експресії полігенів та їхньої взаємодії з впливом паратипових факторів (Hoeschele, 1988; Hyl and Kovalenko, 2010).

Ентропійно-інформаційний аналіз (ЕIA) ознак відтворювальної здатності корів суміжних поколінь показав їхню високу детермінованість. Збільшення оцінок безумовної ентропії для тривалості сервіс-періоду в дочірньому поколінні кожної з досліджуваних порід свідчить про існування протиріччя між продуктивни- ми та відтворювальними якостями у молочних корів (Pidpala et al., 2016; Kozyr and Barabash, 2017).

Враховуючи, що для порід, типів, ліній, стад молочної худоби характерний популяційний рівень організації систем, відповідно рівень ентропії необхідно визначити в суміжних поколіннях тварин. Це своєю чергою дозволить пояснити механізм прогресивного розвитку системи (породи, типу, стада, лінії, родини) з урахуванням іiі стану, тобто складності, упорядкованості та організованості.

Метою дослідження є оцінка розвитку ознак у тварин молочної худоби голштинської породи різної селекції у суміжних поколіннях 3 використанням ентропійно-інформаційного аналізу. Для досягнення зазначеної мети вирішувалися такі завдання: визначити ступінь організованості та інформативності продуктивних ознак корів голштинської породи; встановити значення ентропії для ознак відтворювальної здатності тварин; оцінити стан системи (стада) за адаптаційною здатністю молочної худоби голштинської породи різної селекції.

\section{Матеріал і методи дослідження}

У племінному заводі великої рогатої худоби СТОВ «Промінь» Арбузинського району Миколаївської області було сформовано дослідні групи 3 корівпервісток голштинської породи: перша - імпортовані тварини 3 Німеччини ( $\mathrm{n}=181)$; друга - їхні дочки, тобто тварини власної репродукції $(\mathrm{n}=181)$; третя тварини української селекції $(\mathrm{n}=175)$ і четверта - іхні дочки $(\mathrm{n}=175)$. Впроваджена технологія виробництва забезпечує комфортність експлуатації молочної худоби і реалізацію генетичного потенціалу голштинської породи за подібних умов цілорічно стійлового безприв'язного боксового утримання і однотипної годівлі повнораціонними моносумішами. Середній надій на одну корову в 2016 році становив 10722 кг молока.

Матеріалом для дослідження були дані молочної продуктивності корів-первісток голштинської породи. Відтворювальну здатність піддослідних тварин оцінювали за тривалістю сервіс-, міжотельного, сухостійного періодів та за коефіцієнтом відтворювальної здатності $\quad($ КВ3 = 365/MOП). Індекс адаптації (Siratskyi et al., 2005) визначали за формулою:

$$
\mathrm{I}=\frac{365-\mathrm{MO \Pi}}{\mathrm{M}} \times 27,40,
$$

де $I$ - індекс адаптації; МОП - міжотельний період, тобто інтервал між останім і попереднім отеленням, дн.; 365 - кількість днів у році; МЖ - молочна 
продуктивність корови за закінчену, укорочену або за 305 днів лактації, виражена в кг молочного жиру; 27,40 - постійний коефіцієнт. Максимальне значення індексу становить $+37,0$, мінімальне - $-192,0$, а в ідеалі (МОП = 365 дн.) індекс дорівнює нулю.

Оцінку безумовної ентропії в суміжних поколіннях корів голштинської породи різної селекції проводили за формулою:

$$
\mathrm{H}=-\sum_{i=1}^{k}\left(p_{i} * \log p_{i}\right),
$$

де $\mathrm{p}_{\mathrm{i}}$ - частота того, що система приймає становище $3 \mathrm{k}$ можливих.

Максимально можливу, теоретично визначальну ентропію для даної системи розрахували за формулою:

$$
\mathrm{H}_{\max }=\log _{2} \mathrm{k}=\log _{2} 10=3,322
$$

Максимально можлива ентропія для окремої системи залежить від лімітів точності. У нашому дослідженні кількість таких лімітів дорівнює десяти. Відповідно до їхньої кількості максимальне значення ентропії становить 3,322 .

Рівень абсолютної організації системи суміжних поколінь оцінювали за формулою:

$$
\mathrm{O}=\mathrm{H}_{\max }-\mathrm{H}
$$

Організованість або упорядкованість системи вимірювалась ступенем відхиленя від максимально неупорядкованого стану системи ознаки, що знаходиться в термодинамічній рівновазі, за формулою:

$$
\mathrm{R}=1-\frac{H}{H_{\max }}
$$

Ентропійно-інформаційний аналіз проведено з використанням модифікації для кількісних ознак, запропонованої С.С. Крамаренко (Kramarenko, 2005).

\section{Результати та їх обговорення}

Серед молочної худоби голштинська порода набула найбільшого поширення в багатьох країнах світу, а тому іï схрещували з різними місцевими породами. Це й пояснює складність голштинської породи як біосистеми, що підпорядкована дії різних цілеспрямованих методів селекції, технологічних та природнокліматичних умов. За оцінюваними показниками молочної продуктивності їхня детермінованість невисока, оскільки на розвиток ознак впливають багато факторів. Встановлено відмінності за рівнем інформативності у корів голштинської породи німецької та української селекції. Вищим рівнем детермінованості характеризувалися ознаки: вміст жиру і білка в молоці як голштинських корів-перівсток німецької, так й української селекції. Порівняно $з$ матерями у дочок не лише вищий рівень інформативності, а й більша детермінованість цих ознак (табл. 1). Хоча вірогідний вплив фактору «генерація» було встановлено лише для вмісту жиру в молоці (двофакторний дисперсійний аналіз без повторюваностей: $\mathrm{p}=0,030)$.

Найменшими значеннями абсолютної організованості системи характеризувалися ознаки, розвиток яких у значній мірі обумовлено факторами середовища (надій, кількість молочного жиру, кількість молочного білка, кількість молочного жиру за добу).

Згідно з існуючою класифікацією С. Біра (Bir, 1963), система є ймовірнісною (стохастичною), якщо значення відносної організованості системи $R \leq 0,1$; система вважається детермінованою, якщо $R>0,3$ і система $\epsilon$ квазідетермінованою (ймовірніснодетермінованою), для якої $0,1<R \leq 0,3$.

Більшість досліджуваних ознак, враховуючи рівень відносної організованості $(R)$, можна розглядати як ймовірнісні (стохастичні) системи, за винятком ознаки «вміст білка в молоці», систему якої згідно 3 класифікацією за $R$ можна вважати квазідетермінованою (ймовірнісно-детермінованою).

У таблиці 2 наведено ЕІА ознак відтворювальної та адаптаційної здатності корів голштинської породи.

\begin{tabular}{|c|c|c|c|c|c|c|}
\hline \multirow{2}{*}{ Порода, селекція } & \multirow{2}{*}{ Покоління } & \multirow{2}{*}{$\mathrm{n}$} & \multicolumn{4}{|c|}{ Параметри EIA } \\
\hline & & & $\mathrm{H} \pm \mathrm{SE}_{\mathrm{H}}$, біт & $\mathrm{H}_{\max }$, біт & $\mathrm{O}$, біт & $\mathrm{R}$ \\
\hline \multicolumn{7}{|c|}{ Надій за 305 діб першої лактації } \\
\hline \multirow{2}{*}{$\begin{array}{c}\text { Голштинська, } \\
\text { німецька }\end{array}$} & Дочки & 181 & $3,30 \pm 0,014$ & 3,322 & 0,025 & 0,007 \\
\hline & Матері & 181 & $3,31 \pm 0,011$ & & 0,014 & 0,004 \\
\hline \multirow{2}{*}{$\begin{array}{c}\text { Голштинська, } \\
\text { українська }\end{array}$} & Дочки & 175 & $3,29 \pm 0,016$ & & 0,030 & 0,009 \\
\hline & Матері & 175 & $3,32 \pm 0,007$ & & 0,007 & 0,002 \\
\hline \multicolumn{7}{|c|}{ Вміст жиру в молоці } \\
\hline \multirow{2}{*}{$\begin{array}{c}\text { Голштинська, } \\
\text { німецька }\end{array}$} & Дочки & 181 & $2,53 \pm 0,063$ & 3,322 & 0,791 & 0,238 \\
\hline & Матері & 181 & $3,03 \pm 0,039$ & & 0,292 & 0,088 \\
\hline \multirow{2}{*}{$\begin{array}{c}\text { Голштинська, } \\
\text { українська }\end{array}$} & Дочки & 175 & $2,27 \pm 0,074$ & & 1,056 & 0,318 \\
\hline & Матері & 175 & $2,82 \pm 0,054$ & & 0,507 & 0,152 \\
\hline \multicolumn{7}{|c|}{ Кількість молочного жиру } \\
\hline \multirow{2}{*}{$\begin{array}{c}\text { Голштинська, } \\
\text { німецька }\end{array}$} & Дочки & 181 & $3,30 \pm 0,013$ & 3,322 & 0,021 & 0,006 \\
\hline & Матері & 181 & $3,30 \pm 0,013$ & & 0,020 & 0,006 \\
\hline \multirow{2}{*}{$\begin{array}{c}\text { Голштинська, } \\
\text { українська }\end{array}$} & Дочки & 175 & $3,26 \pm 0,022$ & & 0,062 & 0,019 \\
\hline & Матері & 175 & $3,30 \pm 0,013$ & & 0,020 & 0,006 \\
\hline
\end{tabular}

\section{Таблиця 1}

Стан системи (стада) за ознаками продуктивності у корів суміжних поколінь голштинської породи різної селекції 


\begin{tabular}{|c|c|c|c|c|c|c|}
\hline \multicolumn{7}{|c|}{ Вміст білка в молоці } \\
\hline \multirow{2}{*}{$\begin{array}{c}\text { Голштинська, } \\
\text { німецька }\end{array}$} & Дочки & 181 & $2,78 \pm 0,061$ & 3,322 & 0,541 & 0,163 \\
\hline & Матері & 181 & $2,73 \pm 0,058$ & & 0,596 & 0,180 \\
\hline \multirow{2}{*}{$\begin{array}{c}\text { Голштинська, } \\
\text { українська }\end{array}$} & Дочки & 175 & $2,53 \pm 0,068$ & & 0,794 & 0,239 \\
\hline & Матері & 175 & $2,74 \pm 0,063$ & & 0,584 & 0,176 \\
\hline \multicolumn{7}{|c|}{ Кількість молочного білка } \\
\hline \multirow{2}{*}{$\begin{array}{c}\text { Голштинська, } \\
\text { німецька }\end{array}$} & Дочки & 181 & $3,29 \pm 0,016$ & 3,322 & 0,031 & 0,009 \\
\hline & Матері & 182 & $3,31 \pm 0,012$ & & 0,016 & 0,005 \\
\hline \multirow{2}{*}{$\begin{array}{c}\text { Голштинська, } \\
\text { українська }\end{array}$} & Дочки & 175 & $3,31 \pm 0,011$ & & 0,016 & 0,005 \\
\hline & Матері & 175 & $3,31 \pm 0,010$ & & 0,011 & 0,003 \\
\hline \multicolumn{7}{|c|}{ Надій за першу лактацію } \\
\hline \multirow{2}{*}{$\begin{array}{c}\text { Голштинська, } \\
\text { німецька }\end{array}$} & Дочки & 181 & $3,20 \pm 0,028$ & 3,322 & 0,121 & 0,037 \\
\hline & Матері & 181 & $3,13 \pm 0,033$ & & 0,190 & 0,057 \\
\hline \multirow{2}{*}{$\begin{array}{c}\text { Голштинська, } \\
\text { українська }\end{array}$} & Дочки & 175 & $3,11 \pm 0,032$ & & 0,210 & 0,063 \\
\hline & Матері & 175 & $3,24 \pm 0,024$ & & 0,086 & 0,026 \\
\hline \multicolumn{7}{|c|}{ Кількість молочного жиру за лактацію } \\
\hline \multirow{2}{*}{$\begin{array}{c}\text { Голштинська, } \\
\text { німецька }\end{array}$} & Дочки & 181 & $3,20 \pm 0,028$ & 3,322 & 0,117 & 0,035 \\
\hline & Матері & 181 & $3,11 \pm 0,036$ & & 0,213 & 0,064 \\
\hline \multirow{2}{*}{$\begin{array}{c}\text { Голштинська, } \\
\text { українська }\end{array}$} & Дочки & 175 & $3,14 \pm 0,032$ & & 0,184 & 0,055 \\
\hline & Матері & 175 & $3,18 \pm 0,030$ & & 0,141 & 0,042 \\
\hline \multicolumn{7}{|c|}{ Кількість молочного жиру за добу (А) } \\
\hline \multirow{2}{*}{$\begin{array}{c}\text { Голштинська, } \\
\text { німецька }\end{array}$} & Дочки & 181 & $3,31 \pm 0,011$ & 3,322 & 0,016 & 0,005 \\
\hline & Матері & 181 & $3,30 \pm 0,012$ & & 0,018 & 0,006 \\
\hline \multirow{2}{*}{$\begin{array}{c}\text { Голштинська, } \\
\text { українська }\end{array}$} & Дочки & 175 & $3,30 \pm 0,013$ & & 0,022 & 0,007 \\
\hline & Матері & 175 & $3,30 \pm 0,013$ & & 0,021 & 0,006 \\
\hline
\end{tabular}

\section{Таблиця 2}

Стан системи (стада) за ознаками відтворювальної та адаптаційної здатності у корів суміжних поколінь голштинської породи різної селекції

\begin{tabular}{|c|c|c|c|c|c|c|}
\hline \multirow{2}{*}{ Порода, селекція } & \multirow{2}{*}{ Покоління } & \multirow{2}{*}{$\mathrm{n}$} & \multicolumn{4}{|c|}{ Параметри ЕIA } \\
\hline & & & $\mathrm{H} \pm \mathrm{SE}_{\mathrm{H}}$, біт & $\mathrm{H}_{\max }$, бiт & $\mathrm{O}$, біт & $\mathrm{R}$ \\
\hline \multicolumn{7}{|c|}{ Тривалість першої лактації } \\
\hline \multirow{2}{*}{$\begin{array}{c}\text { Голштинська, } \\
\text { німецька }\end{array}$} & Дочки & 181 & $2,79 \pm 0,057$ & 3,322 & 0,536 & 0,161 \\
\hline & Матері & 181 & $2,70 \pm 0,055$ & & 0,618 & 0,186 \\
\hline \multirow{2}{*}{$\begin{array}{c}\text { Голштинська, } \\
\text { українська }\end{array}$} & Дочки & 175 & $3,00 \pm 0,036$ & & 0,320 & 0,096 \\
\hline & Матері & 175 & $2,93 \pm 0,041$ & & 0,389 & 0,117 \\
\hline \multicolumn{7}{|c|}{ Сервіс-період } \\
\hline \multirow{2}{*}{$\begin{array}{c}\text { Голштинська, } \\
\text { німецька }\end{array}$} & Дочки & 181 & $2,75 \pm 0,054$ & 3,322 & 0,568 & 0,171 \\
\hline & Матері & 181 & $2,61 \pm 0,063$ & & 0,707 & 0,213 \\
\hline \multirow{2}{*}{$\begin{array}{l}\text { Голштинська, } \\
\text { українська }\end{array}$} & Дочки & 175 & $2,96 \pm 0,043$ & & 0,364 & 0,110 \\
\hline & Матері & 175 & $2,90 \pm 0,046$ & & 0,423 & 0,127 \\
\hline \multicolumn{7}{|c|}{ Сухостійний період } \\
\hline \multirow{2}{*}{$\begin{array}{c}\text { Голштинська, } \\
\text { німецька }\end{array}$} & Дочки & 181 & $2,34 \pm 0,073$ & 3,322 & 0,978 & 0,294 \\
\hline & Матері & 181 & $1,74 \pm 0,064$ & & 1,580 & 0,476 \\
\hline \multirow{2}{*}{$\begin{array}{c}\text { Голштинська, } \\
\text { українська }\end{array}$} & Дочки & 175 & $2,94 \pm 0,048$ & & 0,382 & 0,115 \\
\hline & Матері & 175 & $2,84 \pm 0,057$ & & 0,477 & 0,144 \\
\hline \multicolumn{7}{|c|}{ Міжотельний період } \\
\hline \multirow{2}{*}{$\begin{array}{c}\text { Голштинська, } \\
\text { німецька }\end{array}$} & Дочки & 181 & $2,84 \pm 0,054$ & 3,322 & 0,482 & 0,145 \\
\hline & Матері & 181 & $2,82 \pm 0,053$ & & 0,506 & 0,152 \\
\hline \multirow{2}{*}{$\begin{array}{c}\text { Голштинська, } \\
\text { українська }\end{array}$} & Дочки & 175 & $2,94 \pm 0,046$ & & 0,382 & 0,115 \\
\hline & Матері & 175 & $2,93 \pm 0,057$ & & 0,394 & 0,119 \\
\hline \multicolumn{7}{|c|}{ Коефіцієнт відтворювальної здатності } \\
\hline \multirow{2}{*}{$\begin{array}{c}\text { Голштинська, } \\
\text { німецька }\end{array}$} & Дочки & 181 & $3,05 \pm 0,040$ & 3,322 & 0,275 & 0,083 \\
\hline & Матері & 182 & $2,97 \pm 0,053$ & & 0,348 & 0,105 \\
\hline \multirow{2}{*}{$\begin{array}{c}\text { Голштинська, } \\
\text { українська }\end{array}$} & Дочки & 175 & $3,13 \pm 0,039$ & & 0,196 & 0,059 \\
\hline & Матері & 175 & $3,15 \pm 0,038$ & & 0,172 & 0,052 \\
\hline \multicolumn{7}{|c|}{ Індекс адаптації } \\
\hline \multirow{2}{*}{$\begin{array}{c}\text { Голштинська, } \\
\text { німецька }\end{array}$} & Дочки & 181 & $3,13 \pm 0,039$ & 3,322 & 0,194 & 0,058 \\
\hline & Матері & 181 & $3,07 \pm 0,044$ & & 0,255 & 0,077 \\
\hline \multirow{2}{*}{$\begin{array}{c}\text { Голштинська, } \\
\text { українська }\end{array}$} & Дочки & 175 & $3,11 \pm 0,037$ & & 0,207 & 0,062 \\
\hline & Матері & 175 & $3,16 \pm 0,036$ & & 0,159 & 0,048 \\
\hline
\end{tabular}


Ознаки, що характеризують відтворювальні та адаптаційні здатності корів, загалом мають нижчі оцінки ентропії, що свідчить про їхню вищу детермінованість і відповідно біологічну цінність. Особливо це стосується тривалості сухостійного періоду в корів голштинської породи німецької селекції $(\mathrm{H}=1,74 \mathrm{i}$ 2,34 біт). Відомо, що він обумовлює фізіологічні процеси у перехідний період між двома лактаціями й відповідно в деякій мірі впливає на молочну продуктивність корів і, особливо, в наступну лактацію.

Характерно, що відносно двох ознак (тривалість першої лактації та тривалість міжотельного періоду) нами було відмічено вірогідний вплив походження (селекції) на ступінь їхньої детермінованості (в обох випадках: $\mathrm{P}<0,05)$. При цьому у тварин німецької селекції рівень організованості за цими ознаками був вищим, ніж для корів української селекції, незалежно від генерації.

\section{Висновки}

Вищим рівнем детермінованості характеризувалися вміст жиру і білка в молоці як у голштинських корів-перівсток німецької, так й української селекції. Порівняно з матерями у дочок не лише вищий рівень інформативності, а й більша детермінованість цих ознак. Вірогідний вплив фактору «генерація» було встановлено лише для рівня детермінованості вмісту жиру в молоці $(\mathrm{p}=0,030)$.

На ступінь детермінованості тривалості першої лактації та тривалості міжотельного періоду вірогідно впливає походження (селекція). У тварин німецької селекції рівень організованості за цими ознаками був вищим, ніж для корів української селекції, незалежно від генерації. Ознаки, що характеризують відтворювальні та адаптаційні здатності корів, загалом мають нижчі оцінки ентропії.

\section{References}

Babik, N.P., \& Fedorovych, Ye.I. (2017). Influence of outbreeding and inbreeding on the productive longevity of dairy cows. Scientific Messenger of Lviv National University of Veterinary Medicine and Biotechnologies. 19(79), 3-8. doi:10.15421/nvlvet7901

Bir, S. (1963). Kibernetika i upravlenie. M.: IL (in Russian).

Hoeschele, I. (1988). Statistical techniques for detection of major genes in animal breeding data. Theoretical and applied genetics. 76(2), 311-319. doi: 10.1007/BF00257861

Grzesiak, W., \& Zaborski, D. (2012). Examples of the Use of Data Mining Methods in Animal Breeding. Data Mining Applications in Engineering and Medicine. 13, 303-324. doi: 10.5772/50893

Ferenz, L.V. (2017). Reproductive ability and milk productivity of cows depending on breeding value of their progenitors. Scientific Messenger of Lviv National University of Veterinary Medicine and Biotechnologies. 19(74), 48-51. doi:10.15421/nvlvet7411

Golova, N.V., Gultiaeva, O.V., Hudyma, V.Yu., Pakholkiv, N.I., Vudmaska, I.V., \& Petruk, A.P. (2017). Effect of dietary propylene glycol or anti-ketosis supplement on biochemical parameters of cows blood plasma. Scientific Messenger of Lviv National University of Veterinary Medicine and Biotechnologies. 19(79), 22-26. doi:10.15421/nvlvet7905

Gu, J.Q., Wang, Z.H., Gao, R.H., \& Wu, H.R. (2017). Cow behavior recognition based on image analysis and activities. International Journal of Agricultural and Biological Engineering. 10(3), 165-174. doi: 10.3965/j.ijabe.20171003.3080

Hyl, M.I. (2008). Systemnyi henetychnyi analiz polihenno zumovlenykh oznak khudoby molochnykh porid : monohrafiia. Mykolaiv: MDAU (in Ukrainian).

Hyl, M.I., \& Kovalenko, V.V. (2010). Efektyvnist vykorystannia entropiino-informatsiinoho analizu $\mathrm{V}$ otsintsi stupenia minlyvosti oznak koriv ukrainskoi chervonoi molochnoi porody riznoi intensyvnosti formuvannia yikh orhanizmu. Tekhnolohiia vyrobnytstva i pererobky produktsii tvarynnytstva: zb. nauk. prats. Bila Tserkva. 3(72), 41-46 (in Ukrainian).

Kramarenko, S.S. (2005). Osobennosti ispol'zovanija jentropijno-informacionnogo analiza dlja kolichestvennyh priznakov biologicheskih objektov. Izvestija Samarskogo nauchnogo centra Rossijskoj akademii nauk. 7(1), 242-247 (in Russian).

Kramarenko, S., Kuzmicheva, N., \& Kramarenko, A. (2017). Principal component analysis of the exterior traits in dairy cows. Scientific Messenger of Lviv National University of Veterinary Medicine and Biotechnologies. 19(79), 48-52 doi:10.15421/nvlvet7910

Kulibaba, S.V., Dolgaya, M.M., \& Ionov, I.A. (2017). Effect of feeding chelate complexes of trace elements on the average daily balance of $\mathrm{Cu}, \mathrm{Zn}$ and $\mathrm{Mn}$ in the organism of cows during the period of lactation. Scientific Messenger of Lviv National University of Veterinary Medicine and Biotechnologies. 19(79), 58-61. doi:10.15421/nvlvet7912

Kozyr, V.S. \& Barabash, V.I. (2017). Influence of natural selection on the reproductive function of bulls. Agricultural Science and Practice. 4(1), 20-27. doi: 10.15407/agrisp4.01.020

Levitskaya, L.G. (2017). The needs and characteristics of feeding dairy cows. Scientific Messenger of Lviv National University of Veterinary Medicine and Biotechnologies. 19(79), 62-67. doi:10.15421/nvlvet7913

Merkur'eva, E.K., \& Bertazin, A.B. (1989). Primenenie jentropijnogo analiza i kojefficienta informativnosti pri ocenke selekcionnyh priznakov $\mathrm{v}$ molochnom skotovodstve. Doklady VASHNIL. M. 2, 21-23 (in Russian).

Mil'ko, O.S. (1993). Jentropijnyj analiz kak novyj metod izuchenija geneticheskogo vlijanija predkov na porodu. Mat. I Mezhdunarodnoj konferencii po chastnoj genetike sel's'kohozjajstvennyh zhivotnyh. (Askanija-Nova, 18-20 maja 1993 g.): Nauchnyj sovet po problemam genetiki i selekcii Rossijskoj akademii nauk, UAAN, Institut obshhej genetiki im. N. I. Vavilova RAN, Institut zhivotnovodstva stepnyh rajonov «Askanija-Nova». Askanija-Nova, 85 (in Russian).

Patrieva, L.S., \& Kramarenko, S.S. (2007). Entropiinyi analiz kilkisnykh oznak dlia selektsiinoi otsinky 
batkivskoho stada miasnykh kurei. Rozvedennia i henetyka tvaryn: mizhvid. temat. zb. K.: Ahrarna nauka. 41, 149-153 (in Ukrainian).

Palazzolo, J.A., Estafanous, F.G., \& Murray, P.A. (1998). Entropy measures of heart rate variation in conscious dogs. American Journal of Physiology-Heart and Circulatory Physiology. 274(4), H1099-H1105. doi: 10.1152/ajpheart.1998.274.4.H1099

Pelekhaty, M., Piddubna, L., Kochuk-Yashchenko, A. \& Kucher, D. (2017). Comparative characteristics of first-calf cows productivity of modern dairy breeds under the condition of one farm. Biologia Tvarin, 19(3), 69-76. doi: 10.15407/animbiol19.03.069

Pidpala, T.V., Kramarenko, S.S., \& Bondar, S.O. (2016). Zastosuvannia entropiinoho analizu dlia otsinky selektsiinykh oznak molochnoi khudoby. Visnyk Sumskoho natsionalnoho ahrarnoho universytetu: naukovo-metodychnyi zhurnal: seriia «Tvarynnytstvo». 7(30), 89-93 (in Ukrainian).
Pidpala, T.V., Voinalovych, S.A., Nazarenko, V.H., Herasemenko, V.V., Strikha, L.O., \& Tskhvitava, O.K. (2012). Selektsiia molochnoi khudoby i svynei: navch. Posibnyk. Mykolaiv: MNAU (in Ukrainian).

Siratskyi, Y.Z., Merkushyn, V.V., Fedorovych, Ye.I., \& Danylkiv, Ya.N. (2005). Metody otsinky adaptatsiinoi zdatnosti tvaryn. Metodyky naukovykh doslidzhen iz selektsii, henetyky ta biotekhnolohii u tvarynnytstvi. K.: Ahrarna nauka, 74-77 (in Ukrainian).

Smetana, O.Yu. (2009). Stupin orhanizovanosti polihenno zumovlenykh oznak holshtynskoi khudoby za riznykh efektiv vplyvu na nykh stabilizuiuchoho vidboru. Tavriiskyi naukovyi visnyk. Kherson: Ailant. 64(3), 110-118 (in Ukrainian).

Zubec, M.V. (1997). Genetika, selekcija i biotehnologija v skotovodstve. Kiev: «BMT» (in Russian). 